\title{
SELECTION OF BULL DAMS IN POPULATION OF SIMMENTAL CATTLE
}

\author{
V. Pantelić, Ž. Novaković, D. Ostojić-Andrić \\ Institute for Animal Husbandry, 11080, Belgrade-Zemun, Republic of Serbia \\ Corresponding author: vladapantelic.izs@gmail.com \\ Invited paper
}

Abstract: Increase of production and improvement of the quality of milk, as well as of the intensity of fertility, are main prerequisites of modern cattle production. For the purpose of production of domestic Simmental bulls it is necessary to select the best cows from main herd. These heads as a rule represent approx. $1 \%$ of best cows in the controlled population primary in regard to production of milk and milk fat, but also in regard to body development, udder development and fertility traits. Fertilization of bull dams is done according to adequate system, where, for each dam, annually, bull, previously selected as sire, is determined, whose semen will be used for her insemination. Since the fastest way for selection and genetic progress is sire-son line, the most attention is directed to selection of bull sires. In Serbia, annually, only very few bulls are tested, which is insufficient for realization of greater and faster genetic improvement of production and reproduction traits of Simmental population of cattle. Therefore, centres for artificial insemination often import semen of elite bulls for planned insemination of Simmental bull dams, or borrow young bulls from abroad (waiting bulls) whose semen is used for insemination of main population. In this paper criteria for selection of cows into category of bull dams are presented as well as results relating to milk production, fertility, body development and type score of bull dams of Simmental breed in Central Serbia.

Key words: Simmental breed, bull dams, bull sires, selection.

\section{Introduction}

Simmental breed is predominant in Serbia. It is characterized by certain variability especially in regard to production and reproduction traits. In selection and implementation of improved conditions of housing and nutrition, significant efforts have been made for the purpose of increase of production of milk and milk 
fat, but genetic potentials of this breed still haven't been utilized to the full potential.

Milk yield of Simmental cattle in Serbia is lower compared to other main rearing regions in Europe: Austria, Germany, Switzerland, France, etc. Production capacity of Simmental cows in conditions present in Serbia so far was $5.000 \mathrm{~kg}$ of milk with $3,9 \%$ of milk fat, but there is room for improvement to the realization of level present in developed European countries. Increase of production and improvement of the quality of milk, as well as of the intensity of fertility, are main prerequisites of modern cattle production.

Improvement of cattle in sense of improvement of the genetic basis of the population of cattle for milk production, production of milk fat and content of milk fat in present conditions is done through bull sires and bull dams. By application of high quality breeding animals with proven genetic capacity (sons of bull dams and bull sires) production and reproduction traits of cattle population in Serbia can be improved.

\section{Simmental breed}

In breed structure of cattle in Republic of Serbia, it is estimated that Simmental breed participates with approx. 45\%, Domestic spotted cattle of Simmental type approx. 35\%, group of Black and White, Holstein-Friesian cattle with approx. $10 \%$, whereas primitive breeds and crosses make approx. $10 \%$ of total cattle population. Simmental breed is predominant in Central Serbia, as breed of combined production traits. In regions of more intensive cattle production dairy breeds are reared, and in hilly-mountainous regions less productive heads of cattle used of meat-milk production direction.

In regard to its genotype, this breed represents «plastic genome» for more emphasized production of milk or meat, depending on the market tendencies. This is not the characteristic of one production direction specialized breeds. In conditions when international specialization of production is impossible it is necessary to cultivate breeding of cattle of combined traits.

Simmental cattle has well developed chest in depth, width and length. Pelvis is wide which is very important for calving, croup is very muscular, legs are strong, of good position and with correct dew claws, which is very important for good health and longevity of cows. This breed is very healthy and resistant from the aspect of fitness and represents dual purpose breed with high yields in production of milk and meat.

Male calves are characterized by rapid growth and are very well suited for successful fattening of cattle and provide to dairy farms additional source of income. In intensive conditions of fattening, young bulls realize daily gains of over $1400 \mathrm{~g}$, age at slaughtering of 16 to 18 months and slaughter yield of 57 to $60 \%$. 
This important trait of Simmental breed was neglected in breeding process in the past. Except for the fact that marketing of cows and calves represents additional source of income in dairy farming, fattening capacity represents part of morphological traits and health condition of the animal.

Simmental breed adapts easily on most diverse conditions of housing and nutrition. Considering the anatomical and physiological characteristics, Simmental cattle are especially suited for small farms of combined production direction. For successful utilization on large farms it is necessary to implement certain new technological procedures and correct dairy and milking characteristics. No breed is ideal, and this is case also with Simmental breed. Therefore, it needs improvement which can be achieved by constant selection-breeding work. This relates primary to udder, calving and leg firmness.

\section{Selection of bull dams}

Bull dams are chosen exclusively from main population. Cows which represent top of the genetic value of population in regard to their production traits are selected as bull dams. Selection is based on the origin, production traits (amount of milk, milk fat and protein content), milking traits, reproductive indicators, exterior and linear type score. Selection of bull dams is done by board/committee consisting of 3 members:

- representative of the republic selection organization/institution

- representative of district (regional) organization/institution

- representative of a livestock-veterinary centre.

Selection of cows to herd of bull dams in Republic of Serbia is done after the first lactation, i.e. based on subsequent lactations. When selected for bull dams, cows are measured and linearly scored for type or frame, muscularity, form (appearance) and udder, according to Rulebook on evaluation of traits of breeding livestock (Službeni glasnik RS, 1996). Also, it has to be pointed out that cows which are considered to be bull dams have to be of absolutely calm temperament. This is the reason why, in future, integration of this trait should be included in estimation of breeding value. Some studies have shown significant genetic effect of temperament and behaviour during milking.

Also, in future selection-breeding work, in selection of bull dams as in case of bull sires, it should be insisted on selection based on breeding value calculated by the head Republic selection organization/institution obtained based on data on milk production and exterior (linear scoring). 
In innovating of breeding programs world wide young cows are used especially in embryo transfer and it is considered if by shortening of generation interval the reliability of selection is compensated. The opinion is prevailing that it is justified to select young cows into the category of bull dams since in this way output of cow is sacrificed for its longevity (Caput et al. 2005).

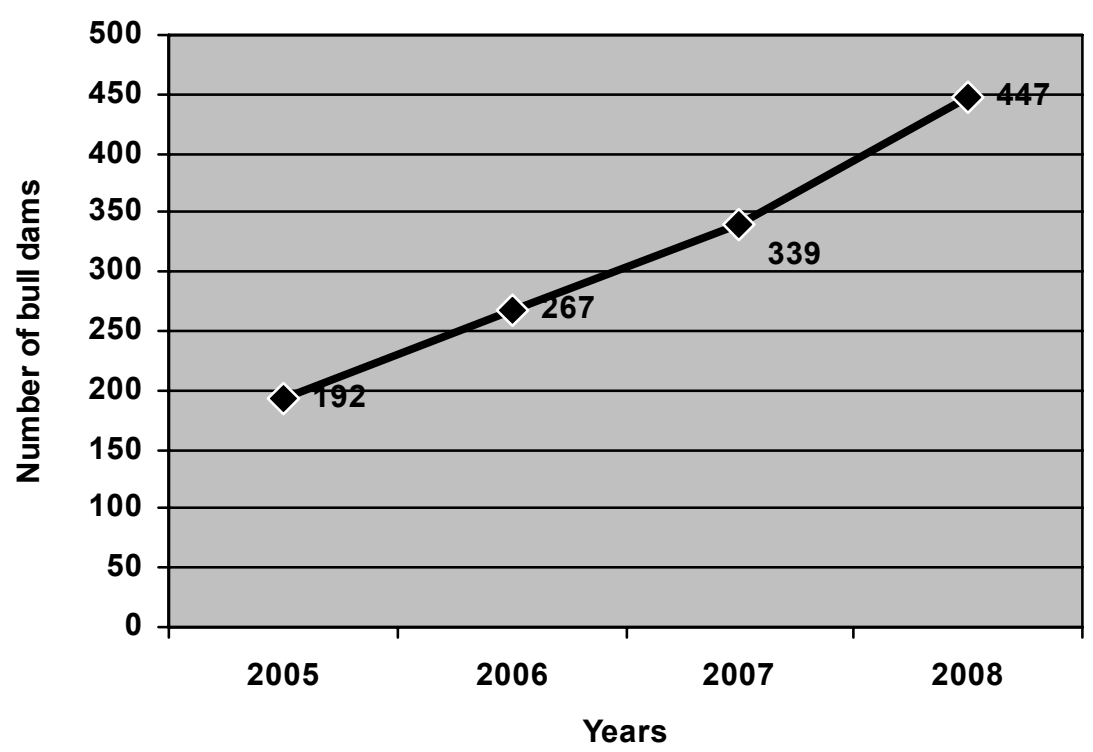

Graph 1. Number of bull dams in Central Serbia in period from 2005 to 2008

With development of methods of molecular genetics genes are discovered which determine some of quantitative traits. Applications based on genetic diagnostics have become integral part of modern process of breeding. Tests of origin which are based on genome (DNA tests in accordance with international standards) have been established as routine method in breeding of German Fleckvieh breed. Genetic diagnostics and tests which are based on markers are becoming more important in detection of anomalies and hereditary defects. Allinclusive monitoring programs for detection of anomalies enable identification and timely selection prior to utilization in rearing and in this way introduction of undesired genes into population is reduced to minimum.

Number of bull dams in previous four year period varied from 192 in 2005 to 447 in 2008 (Graph 1). 


\section{Milk traits of bull dams}

According to data of head selection organization/institution of the Republic of Serbia - Institute for Animal Husbandry, Belgrade-Zemun, average milk yield of bull dams in first lactation at the level of Central Serbia in 2008 was $5.540 \mathrm{~kg}$ of milk with $3,97 \%$ of milk fat, i.e. $218,8 \mathrm{~kg}$ of milk fat (Table 1). Average maximum lactation milk yield was $6.503 \mathrm{~kg}$ of milk with $3,99 \%$ and $257,8 \mathrm{~kg}$ of milk fat. Average duration of first lactation was 310 days and maximum lactation duration 316 days (Institut za stočarstvo, 2009).

Table 1. Milk traits of Simmental bull dams in period from 2005 to 2008

\begin{tabular}{|c|c|c|c|c|c|c|c|c|c|}
\hline \multirow{2}{*}{ Year } & \multirow{2}{*}{ No. } & \multicolumn{4}{|c|}{ First lactation } & \multicolumn{4}{c|}{ Maximum lactation } \\
\cline { 3 - 10 } & & Days & $\begin{array}{c}\text { Milk } \\
\mathrm{kg}\end{array}$ & $\begin{array}{c}\text { MF } \\
\%\end{array}$ & $\begin{array}{c}\text { MF, } \\
\mathrm{kg}\end{array}$ & Days & $\begin{array}{c}\text { Milk } \\
\mathrm{kg}\end{array}$ & $\begin{array}{c}\text { MF } \\
\%\end{array}$ & $\begin{array}{c}\text { MF, } \\
\mathrm{kg}\end{array}$ \\
\hline 2005 & 192 & 308 & 5177 & 3,89 & 203,3 & 312 & 6450 & 3,88 & 252,0 \\
\hline 2006 & 267 & 304 & 5318 & 3,92 & 208,3 & 311 & 6426 & 3,93 & 252,4 \\
\hline 2007 & 339 & 307 & 5488 & 3,96 & 217,5 & 313 & 6459 & 3.97 & 256,6 \\
\hline 2008 & 447 & 310 & 5540 & 3,97 & 218,8 & 316 & 6503 & 3,99 & 257,8 \\
\hline
\end{tabular}

In the research related to phenotypic variability of milk traits in Simmental bull dams, Pantelic et al. (2005,) stated production in the first lactation of 4.767,89 $\mathrm{kg}$ with content and yield of milk fat of $3,77 \%$ and $179,07 \mathrm{~kg}$ respectively. Calculated based on 4\% FCM realized production was $4.593,25 \mathrm{~kg}$.

Hrvatsko stočarsko selekcijski centar (2003) in the annual report stated data that during 2002 in Croatia 419 bull dams of Simmental breed were chosen. Average production of milk in standard lactation was $6.238 \mathrm{~kg}$ with $4,10 \%$ and 256 $\mathrm{kg}$ of milk fat. The greatest milk production of $6.477 \mathrm{~kg}$ and $4,14 \%$ of milk fat content i.e. $268 \mathrm{~kg}$ of milk fat was established in the third lactation.

Studying the production and reproduction traits of Simmental bull dams and by application of the method of least squares, Pantelic (2004) established following results in entire lactation: duration of lactation 311 days, milk yield of $5.754 \mathrm{~kg}$, content of milk fat $3.98 \%$, production of milk fat of $230 \mathrm{~kg}$ and yield of $4 \%$ FCM $5.755 \mathrm{~kg}$. 
Table 2. Milk traits of Simmental bull dams in different districts

\begin{tabular}{|l|c|c|c|c|c|c|c|c|c|}
\hline \multirow{2}{*}{ District } & \multirow{2}{*}{ No } & \multicolumn{4}{|c|}{ First lactation } & \multicolumn{4}{c|}{ Maximum lactation } \\
\cline { 3 - 11 } & & Days & $\begin{array}{c}\text { Milk } \\
\mathrm{kg}\end{array}$ & Days & $\begin{array}{c}\text { Milk } \\
\mathrm{kg}\end{array}$ & $\begin{array}{c}\text { Days } \\
\mathrm{kg}\end{array}$ & $\begin{array}{c}\text { Milk } \\
\mathrm{kg}\end{array}$ & $\begin{array}{c}\text { Days } \\
\begin{array}{c}\text { Milk } \\
\mathrm{kg}\end{array}\end{array}$ \\
\hline Kolubara & 45 & 306 & 5285 & 3.96 & 209.8 & 324 & 6836 & 3.99 & 137.9 \\
\hline Podunavlje & 95 & 307 & 5384 & 3.94 & 212.7 & 316 & 6435 & 3.98 & 253.5 \\
\hline Braničevo & 37 & 305 & 5557 & 4.01 & 223.2 & 305 & 6458 & 4.02 & 256.4 \\
\hline Šmadija & 24 & 304 & 5122 & 3.93 & 200.8 & 304 & 6159 & 3.96 & 242.2 \\
\hline Pomoravlje & 27 & 308 & 5753 & 3.92 & 225.4 & 326 & 6464 & 3.92 & 254.2 \\
\hline Bor & 2 & 298 & 4310 & 3.92 & 170.5 & 298 & 4310 & 3.92 & 170.5 \\
\hline Zaječar & 9 & 314 & 4707 & 3.82 & 180.9 & 311 & 5598 & 3.94 & 221.1 \\
\hline Zlatibor & 10 & 315 & 5060 & 3.96 & 200.8 & 303 & 5541 & 4.07 & 225.6 \\
\hline Raška & 42 & 324 & 6282 & 4.03 & 252.9 & 329 & 6982 & 4.03 & 279.8 \\
\hline Rasina & 86 & 317 & 5729 & 4.00 & 229.2 & 320 & 6443 & 4.00 & 257.7 \\
\hline Belgrade & 70 & 307 & 5504 & 3.93 & 216.3 & 312 & 6731 & 3.99 & 268.9 \\
\hline
\end{tabular}

The influences of the breeding region can be major environment factors affecting the milk production. Numerous factors which complement each other are included here, and the most significant are applied management, nutrition, housing system, etc. (Pantelić, 2006). In Table 2. data relating to milk yield of bull dams in different breeding districts is presented. The best milk traits were established in bull dams reared in Raška district - $6.982 \mathrm{~kg}$ of milk with milk fat content of $4.03 \%$ and $279.8 \mathrm{~kg}$ of milk fat. These results are consequence of the fact that most of the elite cows are reared on one very modern and well equipped farm in the vicinity of Kraljevo.

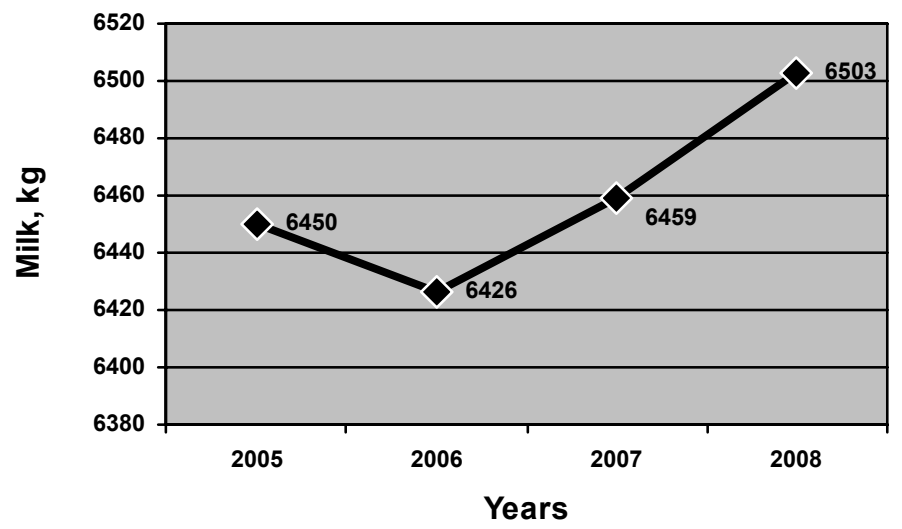

Graph 2. Maximum milk yield of Simmental bull dams in period from 2005 to 2008 
As presented in Graph 2., milk traits of bull dams improved every year, from 2006. High production, with increase of milk yield in relation to previous period, are results of systematic work and high selection criteria in selection, established by the Serbian head selection institution, regional departments and stations, centres for AI, main organizations, as well as producers. Based on all presented it can be concluded that production of milk and milk fat of Simmental bull dams is considerably above average which is realized by registered cows under control in Serbia, but significantly bellow the level of production realized by bull dams in West European countries.

\section{Fertility traits of bull dams}

Fertility problems have become one of the most expensive factors in dairy cattle production. Selection on maternal fertility is becoming more and more important, and requires greater inclusion into estimation of total breeding value. Also, fertility traits which are recorded subjectively, for instance oestrus intensity, should be integrated into breeding value.

Success in improvement of fertility genetically is very limited by low values of heritability, which doesn't mean that they have no effect on this trait, but that the value of additive genetic variation is small. Fertility of cows is significantly more under the influence of environment factors since variation of reproductive traits is mainly under their influence.

By application of standard statistical methods Pantelić (2004) calculated the values of following reproductive indicators of Simmental bull dams presented in Table 3: age at first conception (AFC), duration of service period (SP), duration of pregnancy (DP), and calving interval (CI).

Table 3. Mean values and variability of fertility traits

\begin{tabular}{|c|c|c|c|c|c|c|c|}
\hline & $\mathrm{N}$ & $\mathrm{x}$ & $\mathrm{SD}$ & $\mathrm{CV}$ & $\mathrm{Sx}$ & Min. & Max. \\
\hline AFC & 292 & 515.96 & 99.55 & 19.29 & 0.58 & 297 & 975 \\
\hline DP & 975 & 285.61 & 7.40 & 2.59 & 0.09 & 222 & 346 \\
\hline SP & 881 & 107.30 & 60.76 & 56.62 & 0.26 & 25 & 444 \\
\hline CI & 881 & 393.33 & 60.89 & 15.48 & 0.26 & 263 & 730 \\
\hline
\end{tabular}

Analyzing production and reproduction parameters of Simmental bull dams in our country, Pantelić et al. (2005a) addressed also the problem of their fertility. Using the method of least squares, average age at fist conception of 517,61 days was established, duration of service period of 108,98 days, duration of pregnancy 285,51 days and calving interval 395,34 days in Simmental bull dams. 
Analyzing the effect of certain paragenetic factors on fertility traits of Simmental bull dams, Pantelić et al. (2005b) concluded that obtained research results indicate justification of the research of paragenetic factors since knowledge of their action can contribute to more objective assessment of the random effects. At the same time they established that regions also have highly significant effect $(\mathrm{P}<0,01)$ on age at first conception, duration of service period and duration of period between calving, whereas on duration of pregnancy no significant effect was established ( $p>0.05$ ). Number of lactation (order of lactation) as the second factor analyzed in this research showed no influence on any on the fertility traits $(\mathrm{p}>0.05)$.

If serious problems in reproduction occur, beside direct consequences in regard to milk production and production of milk fat, also difficulties in normal realization of the herd remount are induced and this reflects on economical efficiency of production (Pantelić et al. 2008).

\section{Body development and type of bull dams}

Studying the animal exterior it is possible to certain extent to determine body development of the cow's organism. There is certain relation between body development and production capacity for milk production. However, it is not possible to define according to body development. i.e. exterior of cow, the functionality which is expressed by milk production. Therefore, capacity of cow for milk production can be determined more precisely only by measuring of the production. Phenotype correlations between shape and production characteristics are positive but relatively low, therefore it is not possible to carry out selection from the production aspect according to assessment of animal exterior. Visual evaluation of body development and recognition of milk traits of cows are preliminary indicators of milk production, and partially also of longevity, as well as reproductive capacities of head of cattle, which is also very important from the aspect of economical efficiency of milk production (Pantelić et al., 2006, 2009).

Simmental cows in milk production show very strong front body half, front legs and they maintain satisfactory muscularity of rear body half, which provides stability and health at the peak of lactation. Body proportions are balanced and harmonized, and animals have very healthy legs.

Prerequisite for perfect type is skeleton which in spite of increase of body size and growth rate, must maintain anatomical balance. Simmental breed has exceptional constitution of the spine, pelvis position and development of ankles. In evaluation of exterior which is limited only to side view/appearance, potential of Simmental cow is not taken into consideration. In animals of this breed, also the «third dimension» has to be included. Its exceptional body width, exceptional capacity of chest and pelvis have the same biological result from the aspect of feed 
conversion and functioning of organs, as well as wide and long circumference of chest/ribs which is demanded for this breed.

From the aspect of udder quality in animals of this breed, work in the future will be necessary in order to reach the level of dairy breeds. Top scores for breeding value force bull sires which are famous for passing on of good udder on to their progeny. Therefore, it is important to introduce consideration of udder quality in sire ranking.

In the report on realization of measures in selection of livestock in Serbia in 1999. Institut za primenu nauke u poljoprivredi , 2000 published data on exterior measures for 610 selected bull dams of Simmental breed: height to withers $136 \mathrm{~cm}$, chest depth $72 \mathrm{~cm}$, body length $163 \mathrm{~cm}$, chest girth $197 \mathrm{~cm}$ and body mass $697 \mathrm{~kg}$.

Same source in the report on realized livestock selection measures in Serbia for 2000 stated data on exterior measures for 565 chosen bull dams of Simmental breed. Compared to 1999, height to withers remained the same - 136 $\mathrm{cm}$. Chest depth increased to $74 \mathrm{~cm}$, body length also to $169 \mathrm{~cm}$, and chest girth to $199 \mathrm{~cm}$. Decrease of body mass by $30 \mathrm{~kg}$ was established - $666 \mathrm{~kg}$ (Institut za primenu nauke u poljoprivredi, 2001).

Exterior measures of chosen Simmental bull dams in 2008 were following: height to wither $138,41 \mathrm{~cm}$, chest depth $76,12 \mathrm{~cm}$, body length $170,42 \mathrm{~cm}$, chest girth 201, $41 \mathrm{~cm}$ and body mass established based on chest girth $689,60 \mathrm{~kg}$ (Institut za stočarstvo, 2009).

Bull dams were linearly scored, during selection or repeated estimation, according to Rulebook on method of estimation of traits of breeding livestock (Official Journal of Republic of Serbia, No. 21, from 16.05.1996). Average values of linear type scores were high which is in concordance with requirements for bull dams: type or frame - 7,97; muscularity - 7,88; form or appearance - 8,05 ; udder 7,83. Pantelić et al. $(2007 a, b)$ studied linear type scoring of Simmental cows and effects of paragenetic factors on linear score in Serbia.

\section{Selection of bull sires}

Since the fastest way of selection and genetic improvement is through sireson line, the most attention is directed towards selection of bull sires. Bull sires for creation of new generation of breeding males intended for artificial insemination are mainly chosen from foreign population (Austria and Germany), and considering the genetic potential, they represent elite breeding animals. In selection of bull sires information about their breeding values for all traits of interest for selection progress are taken into consideration. 
In Serbia, annually, only very few bulls are tested, which is insufficient for realization of greater and faster genetic improvement of production and reproduction traits of Simmental population of cattle. Therefore, centres for artificial insemination often import semen of elite bulls for planned insemination of Simmental bull dams, or borrow young bulls from abroad (waiting bulls) whose semen is used for insemination of main population.

Rearing of male calves from planned mating is realized in the centre for artificial insemination where there is performance test station. Based on results of performance test and breeding value of parents bulls are selected for future exploitation. Bulls in testing have to fulfil standards of main breeding program of the AI centre and breeding associations from the aspect of breeding value, phenotype, health status and semen quality.

Genetic value of bulls can be assessed based on their own performance, i.e. results. Also, physical attributed of breeding male can be of help in selection. Genetic values which are also often available include results of his parents, grandparents, siblings and other heads in the herd.

After selection of bull sires and dams, the insemination plan is developed. Fertilization of bull dams should be done according to specially developed programmed directed fertilization. It is necessary to take into consideration other production, exterior and functional traits. Objective is healthy, fertile cow of good longevity which will produce lot of milk, be of good, firm constitution, suitable body frame, firm and well developed legs and dew claws, with well attached, long and spacious udder with well developed and positioned teats.

Production of milk and milk fat is limited to one sex, so potential ability of breeding males for these traits is established based on production results of his mother, sisters and daughters. Information about the quality of bulls and knowledge of how certain traits are passed on to progeny are central issues of breeding programs. Application of artificial insemination and long term storing of semen cause reduction of number of bulls in populations, therefore their individual effect on results of selection and crossing is significantly higher.

Realization of genetic progress in cattle production is usually achieved in smaller elite populations, so called nucleus herds, and subsequently, using various breeding procedures realized genetic progress is expended on the remaining population. How will realized genetic progress in nucleus herd be transmitted to remaining population depends on several factors among which are the complexity of breeding program, bio-economical characteristics of traits, level of selection intensity, remount percentage, duration of genetic interval, etc. (Bogdanović et al., 2008). 


\section{Conclusion}

Cows which represent top of the genetic value of the population are selected to be bull dams. Selection is based on production traits (quantity of milk, content of milk fat and proteins), milking traits, reproduction indicators, exterior and linear type scores. In future, breeding-selection activities in selection of bull dams, same as for bull sires, should be based on breeding value calculated and established by the head selection organization/institution of the Republic of Serbia, based on data on milk production and exterior (linear scoring).

Production of milk and milk fat on Simmental bull dams is significantly above average realized by heads of cattle in main population which are under control in Serbia, but significantly bellow production of bull dams in West European countries.

Fertility problems have become one of the most expensive factors in dairy cattle production. Selection on maternal fertility is becoming more and more important, and requires greater inclusion into estimation of total breeding value. If serious problems in reproduction occur, beside direct consequences in regard to milk production and production of milk fat, also difficulties in normal realization of the herd remount are induced and this reflects on economical efficiency of production

Since the fastest way of selection and genetic improvement is through sireson line, the most attention is directed towards selection of bull sires. Fertilization of bull dams should be done according to specially developed programmed directed fertilization, and special attention has to be directed to production, exterior and functional traits.

Considering anatomical and physiological characteristics, Simmental cattle are best suitable for smaller farms of combined production direction. For successful utilization on big farms, it is necessary to introduce new technological procedures and correction of milk and milking characteristics.

\section{Acknowledgment}

This research is part of the Project TR- 20042 financial supported by Ministry of Science and Technological Development of the Republic Serbia. 


\title{
Selekcija bikovskih majki u populaciji simentalske rase goveda
}

\author{
V. Pantelić, Ž. Novaković, D. Ostojić-Andrić
}

\section{Rezime}

Povećanje proizvodnje i kvaliteta mleka kao i intenziteta plodnosti, osnovni su preduslovi savremene govedarske proizvodnje. Za potrebe proizvodnje bikova simentalske domaće rase neophodno je iz matičnog zapata odabrati najbolje krave. Ova grla, po pravilu, predstavljaju oko $1 \%$ najboljih krava kontrolisane populacije, pre svega u proizvodnji mleka i mlečne masti, a zatim i u telesnoj građi, građi vimena i osobinama plodnosti. Oplođavanje bikovskih majki se obavlja po odgovarajućem sistemu. Svakoj kravi se u toku jedne godine određuje bik čijim će se semenom osemeniti, a koji je prethodno odabran za oca budućih bikova.

Budući da je najbrži put selekcije i genetskog unapređenja osobina putem linije otac-sin, izboru bikovskih očeva se pridaje najveća pažnja. U Srbiji se na godišnjem nivou testira jako mali broj bikova, što je nedovoljno za ostvarivanje nekog većeg i bržeg genetskog poboljšanja proizvodnih i reproduktivnih osobina populacije simentalske rase goveda. Iz tih razloga se centri za veštačko osemenjavanje odlučuju na uvoz semena za plansko oplođavanje bikovskih majki simentalske rase, ili pozajmicu mladih bikova iz inostranstva (čekajuci bikovi) čije seme se upotrebljava za veštačko osemenjavanje matične populacije.

Pored kriterijuma na osnovu kojih se vrši odabiranje krava u kategoriju bikovskih majki u radu su prikazani i rezultati mlečnosti, plodnosti, kao i telesne razvijenosti i ocene tipa bikovskih majki simentalske rase u centralnoj Srbiji.

\section{References}

BOGDANOVIĆ V., ĐEDOVIĆ R., STJELJA S., PERIŠIĆ P., PETROVIĆ D.M., ĐURĐEVIĆ R. (2008): Simulacije genetskog napretka u nukleus yapatu simentalskig goveda i implikacije na odgajivački program. Biotechnology in Animal Husbandry, 24, spec issue, 61-70.

CAPUT P., IVANKOVIĆ A., KONJAČIĆ M. (2005): Koncept uzgojnih programa u govedarstvu Hrvatske. Stočarstvo, 59, 6, 465-476.

INSTITUT ZA PRIMENU NAUKE U POLJOPRIVREDI (2000): Selekcija stoke u Srbiji za 1999. godinu, Beograd.

INSTITUT ZA PRIMENU NAUKE U POLJOPRIVREDI (2001): Selekcija stoke u Srbiji za 2000. godinu, Beograd. 
INSTITUT ZA STOČARSTVO (2009): Stručni izveštaj i rezultati obavljenih poslova koordinacije u 2008. godini, Beograd.

HRVATSKO STOČARSKO SELEKCIJSKI CENTAR (2003): Godišnje izvješće. Zagreb.

PANTELIĆ V. (2004): Fenotipska varijabilnost proizvodnih i reproduktivnih osobina bikovskih majki simentalske rase. Magistarska teza. Poljoprivredni fakultet, Beograd.

PANTELIĆ V., SKALICKI Z., PETROVIĆ M.M., KUČEVIĆ D. (2005a): Reproductive characteristics of simmental breed bull dams. Biotechnology in Animal Husbandry, 21, 1-2, 13-20.

PANTELIĆ V., SKALICKI Z., LATINOVIĆ D., PETROVIĆ M.M., KUČEVIĆ D. (2005b): Ispitivanje dejstva pojedinih paragenetskih faktora na osobine plodnosti bikovskih majki simentalske rase. Biotechnology in Animal Husbandry, 21, 3-4, 35-41.

PANTELIĆ V., SKALICKI Z., PETROVIĆ M.M.,ALEKSIĆ S., MIŠČEVIĆ, B., OSTOJIĆ D. (2005): Phenotipic variability of milk traits in simmental bull dams. Biotehnology in Animal Husbandry, 21, 5-6, 31-34.

PANTELIĆ V., SKALICKI Z., PETROVIĆ M.M., ALEKSIĆ S., MIŠČEVIĆ B., OSTOJIĆ D. (2006): Telesna razvijenost bikovskih majki simentalske rase. Biotechnology in Animal Husbandry, 22, 3-4, 23-32.

PANTELIĆ V., SKALICKI Z., PETROVIĆ M.M., LATINOVIĆ D., ALEKSIĆ S., MIŠČEVIĆ, B., OSTOJIĆ D. (2007a): Linearno ocenjivanje bikovskih majki simentalske rase. Savremena poljoprivreda 1-2, 49-53.

PANTELIĆ V., SKALICKI Z., PETROVIĆ M.M., ALEKSIĆ S., MIŠČEVIĆ, B., OSTOJIĆ-ANDRIĆ D. (2007b): Variability of linearly evaluated traits of type of Simmental bull dams. Biotechnology in Animal Husbandry, Book 1, 201-209.

PANTELIĆ V. (2006); Fenotipska i genetska varijabilnost prizvodnih osobina prvotelki simentalske rase u različitim regionima Srbije. Doktorska disertacija, Poljoprivredni fakultet Zemun - Beograd, 3-173.

PANTELIĆ V., SKALICKI Z., PETROVIĆ M.M., ALEKSIĆ S., OSTOJIĆANDRIĆ D., NOVAKOVIĆ Ž. (2008): The effect of breeding region on certain fertility parameters of simmental cows. Biotechnology in Animal Husbandry, 24, 3-4, 1-8.

PANTELIĆ V., SKALICKI Z., BOGDANOVIĆ V., DELIĆ N., PEJČIĆ S. (2009): The effect of paragenetic factors on body development of simmental bull dams. Biotechnology in Animal Husbandry, 25, 1-2, 53-59.

SLUŽBENI GLASNIK RS (1996): Pravilnik o načinu ispitivanja svojstava priplodne stoke i o uslovima proizvodnje i transporta živine, 693-694. Beograd. 